\title{
IAMJ
}

INTERNATIONAL

AYURVEDIC

MEDICAL JOURNAL

\section{PREVENTIVE AND THERAPEUTIC EFFECT OF YOGĀSANA AND PRĀNĀYAM IN THE PATIENTS OF DIABETES MELLITUS: AN OVERVIEW}

\author{
Rashmi Kathait ${ }^{1}$, Ajai Kumar Pandey ${ }^{2}$
}

${ }^{1} \mathrm{Ph}$. D Scholar, Department of Kayachikitsa, Faculty of Ayurveda, Institute of Medical Science, Banaras Hindu University, Varanasi, Uttar Pradesh, India

${ }^{2}$ Associate Professor, Department of Kayachikitsa, Faculty of Ayurveda, Institute of Medical Science, Banaras Hindu University, Varanasi, Uttar Pradesh, India

Corresponding Author: drrashmikathait@gmail.com

\section{https://doi.org/10.46607/iamj1909102021}

(Published Online: October 2021)

Open Access

(C) International Ayurvedic Medical Journal, India 2021

Article Received: 08/09//2021 - Peer Reviewed: 22/09/2021 - Accepted for Publication: 24/09/2021

\section{Check for updates}

\begin{abstract}
Objective: The present review was carried out with the objectives of identifying the role of Yogāsana (yogic practices) and Prānāyam (breathing practices) as a modality to prevent and treat diabetes. Data Source: The feasible beneficial effects of Yogāsana (yogic practices) and Prānāyam (breathing practices) on diabetes were assessed, which is based on relevant classical texts along with textbooks of contemporary medical sciences. Besides, recent research articles related to clinical studies conducted in various institutions as available on the internet and published in authentic databases (Pub-Med, Google Scholar, Web of Science etc.) were also referred through the ancestry approach. Review Methods: The possible correlation has been made between collected information and has been presented systematically. The quality of the studies was assessed by the author and logically presented in this context. Result and Discussion: Yoga offers a non-invasive way to manage various clinical conditions up to some extent. It can be prescribed with other systems of medicines as an adjuvant for health promotion. Recent evidence suggests that Yoga and controlled lifestyle measures reduce blood sugar load in people with diabetes.
\end{abstract}


Keywords: Yoga, Yogāsana, Prānāyam, Diabetes mellitus, Insulin resistance, lifestyle disease.

\section{INTRODUCTION}

Diabetes mellitus is responsible for more than $60 \%$ of morbidity and death, putting a huge strain on the healthcare system and the economy. India had more people with diabetes than any other country (International Diabetes Foundation) According to the Indian diabetes federation \&Southeast Asia region (IDF SEA); 425 million people have diabetes in the world of which 82 million people are affected with diabetes in the Southeast Asia Region. 72 million cases of diabetes have been reported in India in the year 2017 , and this will rise to 151 million by the year 2045 [1]. The high prevalence is linked to a combination of genetic susceptibility, a high-calorie diet, and a lack of physical activity among India's increasing middle class. (Kleinfield, 2006).

Now a day faulty dietary habits and lifestyle errors are the important causative factors for the genesis of various lifestyle disorders, including obesity and diabetes. Deranged lipid metabolism has been implicated in the core matrix of insulin resistance diathesis in recent years. Diseases such as obesity, metabolic syndrome and Type-2 DM are the outcome of insulin resistance [2]. DM is a vicious and deadly disease that often coexists with other chronic illnesses. Diabetic neuropathy, retinopathy, nephropathy, and diabetic foot gangrene and ulcer make life difficult for both patients and caregivers.

Yogic lifestyle is holistic, and an ideal way of living, which imparts significant inputs for prevention as well as management of ailments. It is a rich heritage of human culture and civilization in India. 1nternational Yoga Day is celebrated on 21st June worldwide, declared unanimously y by the United Nations General Assembly (UNGA) in 2015.

Yoga is not just as physical exercise, but a way of physical, mental and spiritual practices that originated in India. The effectiveness of Yogāsana (yogic practices) and Prānāyam (breathing practices) are mentioned in classical literature for the preservation of health, and the management of various diseases. Now it has become the theme of modern scientific assessment. In recent years, Yogic techniques emerge as the centre of attraction for solving the problems of ailing one. Seeing this fact, the researchers are inclined to assess its safety and efficacy in a healthy and diseased person. In this context, we through some light on the role of Yogāsana (yogic practices) and Prānāyam (breathing practices) practices in people with diabetes based on classical \& neo contemporary evidence.

\section{Objective}

The purpose of this review was to determine the role of Yogāsana (yogic practices) and Prānāyam (breathing practices) as a modality for the prevention and management of diabetes mellitus.

\section{Material and Methods}

The possible beneficial effect of Yogāsana (yogic practices) and Prānāyam (breathing practices) were assessed about DM based on classical texts of Yoga \& Ayurveda along with textbooks of contemporary medical sciences to put essential inputs on diabetes. Besides human clinical trials, the available data on the internet and published in authentic databases (PubMed, MEDLINE, Web of Science etc.) related to Yogāsana (yogic practices) and Prānāyam (breathing practices) on people with diabetes were also referred to put an overview.

\section{Review Methods:}

The present review work is based on research material available in the text of Yoga, published in authentic data sources, contemporary Yoga literature, and related clinical research work conducted at various institutes. This information was initially analyzed, and possible correlation has been made and presented systematically. Step by step, the genuineness of available research was separately observed by the author and laid down an emphasis on Yogāsana (yogic practices) and Prānāyam (breathing practices) on the patients of diabetes mellitus.

A combination of key search terms was used to identify papers that have shown the impact of Yogāsana (yogic practices) and Prānāyam (breathing practices) 
for the prevention, and management of diabetes Mellitus. The following keywords were used for research strategy building: Yogāsana, the role of Yoga, Prānāyam, and diabetes mellitus. These terms were combined in the following way: Yogāsana AND diabetes AND Prānāyam (OR Yogāsana OR Asanas).

\section{YOGA AND DIABETES}

Patanjali offers an eight-fold path to consciousness and enlightenment known as "Ashtanga Yoga" which means "eight limbs," in the yoga sutra [3][4]. The eight limbs express the ethical ideal for living a serene life and attaining solvency in death. It is beneficial to one's physical, mental, social, and spiritual well-being. Although any of the eight limbs can be practiced independently, the physical postures and breathing exercises (as defined by Yoga philosophy) prepare the mind and body for meditation and spiritual development [5] [6]. Yoga is a Sanskrit word that means' union', as in the union of mind, body, and spirit. Āsanas (relaxation exercises), Prānyām (breathing practices), Nourishing diet, Positive attitude, and Meditation are the five basic elements of yoga. Prānyām (breathing practices) is a yogic breathing method that focuses on increasing lung capacity. (Yadav \& Das, 2001; Frostell, 1953) It improves cognitive control and deepens your ability to relax by strengthening the internal organs (Sharma et al. 2005) (Granath, 2006)

Prānāyam (breathing practices) is one of the Yoga techniques which is the least challenging for physically disabled people and, it can be easily practiced in a sitting position (Ramdev, 2005). Yoga has proven its role as an antioxidant by reduction of oxidative stress. It has also shown short term(fasting and post parandial) and long term (HbA1C) glycemic control of people with diabetes through the activation of neuron and endocrine cells (Yadav et al. 2005). Besides, Yogāsana (yogic practices) and Prānāyam (breathing practices) also activate peripheral utilization of blood glucose by the muscles.
Result:

Observation of the Effectiveness of clinical studies on Yogāsana (yogic practices) and Prānāyam (breathing practices):

\section{A. Effect on Glycemic control-}

Yoga practice aids in the management of Type 2 diabetes mellitus (DM 2). A study shows Yoga Asana have beneficial effects in biochemical parameters for chronic Type 2 diabetic elderly subject. The Yoga group was given personalized Yogāsana (yogic practices) and Prānāyam (breathing practices) for six days a week for 12 weeks in the study. Pre- and postintervention biochemical markers were compared between the groups after 12 weeks of intervention. The levels of glycosylated hemoglobin, fasting glucose, and serum lipids all improved significantly [7] [8]. Another prospective case-control study was conducted on 30 patients with diabetes and 30 nondiabetics male volunteers, which revealed that Yoga has shown a significant reduction in fasting and post parandial blood sugar levels at the end of the six months in the patients of T2DM. While on nondiabetic male patients the observed changes in fasting and post parandial blood sugar levels were statistically not significant at the end of six months [9].

Similar findings were found by Vaishali [10], S. Singh et al. [11], Upadhyay et al. [12], and Malhotra et al. [13].

\section{B. Effect on controlling deranged lipid profile}

Dyslipidemia is the primary risk factor for cardiovascular disease in people with diabetes mellitus [14]. A high plasma triglyceride (TG), low high-density lipoprotein (HDL) concentration, and an elevated concentration of small dense low-density lipoprotein (LDL) in the serum are all hallmarks of diabetic dyslipidemia. Insulin resistance causes an increase in the flux of free fatty acids in the blood, resulting in lipid changes [15].

Increased hepatic lipase and lipoprotein lipase, which would increase TG uptake by adipose tissue and influence lipoprotein metabolism, could explain the improvement in lipid profile with Yoga [16].

Yoga intervention was conducted for three months to assess its efficacy in the patients of dyslipidemia hav- 
ing type 2 diabetes mellitus. It showed decreased total cholesterol, TG and low-density lipoprotein, with an improvement in high-density lipoprotein [17]. Based on the findings of another study it can be concluded that long-term Yoga practice will help to maintain blood sugar and lipid profile levels [18]. A study done by Nisha ShantaKumari et al. has shown that Yoga, exercise and stress management training, significantly corrects deranged lipid profiles, lowers body mass index (BMI), and minimizes the macrovascular complications in person with diabetes [19].

\section{Effect on body weight and BMI}

Presently deleterious effects of obesity have been observed in developed as well as in developing countries like India. It has an increased risk of developing various diseases, including type- 2 diabetes, high blood pressure, asthma, heart and kidney-related disease etc. There are many complementary and alternative medicines available to manage such types of physical and mental conditions. Among these, Yoga has played a prominent role in the management of obesity and related complications. Yoga poses ( $\bar{A}$ sanās) work on endocrine glands, improve blood circulation and improve tissue metabolism [20]. The waist-hip ratio was reduced as a result, which is similar to what Sahay et al. reported. They also found a rise in lean body mass and a decrease in skin-fold thickness. Yoga helps in the reduction of central obesity through the redistribution of body fat. It reduces insulin resistance; potentiate insulin receptors \& sensitivity along with the shift to the peak insulin level to the left with normalization of blood glucose level. Thus, in this way, it reduces body weight and BMI [21] [22].

\section{Effect on High blood pressure (HBP)}

By damaging arteries \& making them target for hardening (called atherosclerosis), diabetes can lead to high blood pressure. People with Type I and Type2DM have chances of high blood pressure 25\%,80\%, respectively [23]. LF person with DM having high blood pressure may lead to developing micro \& macro-vascular hemorrhage, cardiovascular accident (CVA) retinal tissue damage (Retinopathy) and kidney disease (Nephropathy) or make them worse. If diabetes with high blood pressure is not treated in due time, it may lead to blood vessel damage, heart attack and kidney failure [24]. Behavioral approaches like stress reduction, increased exercise and healthy dietary habits are recommended for blood pressure reduction. The benefits of Yoga in reducing blood pressure have been proved. However, it has received little attention in existing health care practices in developing countries. A study in Nepal by Dhungana et al. has been established that the package of Yoga intervention significantly minimizes the blood pressure in hypertensive patients [25].

\section{E. Effect on Oxidative stress}

Recent data reveals that oxidative stress plays a key role in the aetiology of lifestyle diseases such as diabetes. In addition, oxidative stress appears to be a pathogenic role in diabetic complications. External factors (ionizing radiation and chemical carcinogens) as well as endogenous mechanisms, such as energy consumption in mitochondria, produce reactive oxygen species (ROS). In living cells, such ROS can simultaneously target lipids, proteins, and nucleic acids. There are a variety of mechanisms and processes through which these ROS could contribute to the development of insulin resistance, b-cell malfunction, diabetes, and other clinical problems [26]. Yoga practices improved the antioxidant levels, thereby reducing the oxidative stress in type 2 diabetic patients. It is found that the Yoga practitioners achieved a $20 \%$ reduction in oxidative stress [27].

\section{F. Effect on stress and anxiety}

Diabetes and mental stress have a close relationship, both affected by each other. High blood sugar levels can cause mood fluctuations, which can put emotional strain on relationships and personal lives. It also causes nervousness, anxiety, and confusion, resulting in diabetic distress. Although these symptoms may not be serious enough for a doctor to diagnose diabetes distress as a mental disease, they can have an impact on a diabetic's quality of life [28]. Yoga practices aid in the proper management of stress, anxiety, and depression and a number of studies have demonstrated the effectiveness of Yoga in the treatment of mental illnesses. 


\section{G. Effects on sleep}

Patients with diabetes mellitus have closely associated with several sleep disorders, of which some are related to the disease itself or complications or related co-morbidities with diabetes. On the other hand, reduced sleep time and irregular sleep patterns have been linked with a higher incidence of obesity, metabolic syndrome, and T2DM [28].

The addition of regular Yoga exercise in the daily routine of older adults can help to achieve good sleep quality and improve their quality of life [29]. People with diabetes are two to three times more prone to develop depression than others (National Institute for Clinical Excellence-NICE-Guidance CG91 2009) [30]. Results of a study by Banker et al.; have shown that older adults routinely practicing Yoga had fewer chances of disturbed sleep, easily falling asleep, had normal daytime functioning, minimal requirement of sleep medications and also felt more energetic. This is because, since Yoga exercises impart muscle stretching and relaxation, may lead to physical and mental exertion resultingin better overall sleep quality and efficiency [31] [32] [33]

\section{H. Effect on Nervous system}

Stress has undoubtedly caused a wide range of health conditions, and Yoga is the foremost comprehensive approach to battling stress [34]. Besides, the relaxation induced by meditation or Prānāyam (breathing practices).helps stabilization of the autonomic nervous system with a tendency towards parasympathetic dominance. (O. Prashad, WIMJ, June 2004). By directly enhancing parasympathetic output, possibly via vagal stimulation, yogic practices help to shift the autonomic nervous system balance from sympathetic to parasympathetic, resulting in positive changes in cardiovagal function and related neuroendocrine, inflammatory, and hemodynamic profiles in sleeprelated metabolic parameters [35]. Raja Yoga meditation is a superior form of meditation in which the natural use of the mind to relieve stress enhances the flow of thoughts. Yoga can help people who have or are at risk of developing type 2 diabetes (DM2) [36].

\section{Effect on to reduce modern medication}

Researchers and scholars are attempting to determine how the Yoga discipline improves general wellness. Yoga can help to reduce the usage of modern pharmaceuticals for various common medical illnesses such as diabetes, HIV, immunological function, osteoarthritis, menopause, multiple sclerosis, Post Traumatic Stress Disorder, and smoking cessation, among others [37].

\section{DISCUSSION}

Yoga has been an enormously evolved science of its kind since antiquity, which offers various physical and mental health benefits and enlightens to achieve the highest level of consciousness.

In India, Yoga, along with Naturopathy is recognized as an official system of medicine. In recent years, Yoga gained momentum regarding its health benefits. The researchers are trying to explore its mechanism of action by adopting tools and techniques of biomedical sciences. The precise mechanisms of yogic intervention in blood sugar reduction remain unknown [38] [39]. The mechanisms that could be used are listed below.

a) Various yogic therapies may directly rejuvenate pancreatic cells. Through an enzymatic process, it may improve glucose consumption and metabolism in peripheral tissues, the liver, and adipose tissues [40].

b) Yoga techniques may lead to muscular relaxation, development and improved blood supply to muscles. It also reduces insulin resistance, which results in higher glucose uptake by muscles, lowering blood sugar levels [41].

c) The Yogāsana (yogic practices) recommended for people with diabetes focuses on the pancreas, the organ responsible for producing insulin. The Yoga poses (such as Manduka-Āsana, paschimottan- Āsana etc.) massage the pancreas, which facilitates the release of toxins from the cells, and improves fresh blood circulation to the respective organs.

- Yogāsana (yogic practices) is linked to weight loss in healthy adults, which helps to avoid the 
onset of many chronic illnesses, including diabetes.

- Blood pressure is linked to the development of diabetes and related complications, and Yoga has been shown to help. Yoga reduces adrenaline, nor-adrenalin and cortisol levels in the blood, collectively known as 'stress hormones. In this way, patients with diabetes are benefited from the practice of Yogāsana (yogic practices) and Prānāyam (breathing practices).

- Âsanas practice helps to rejuvenate the pancreatic beta cells, and thus maintain the desired insulin secretion.

- It also helps to lower blood sugar levels by improving peripheral glucose utilization from the muscles, which comes from the pancreatic beta cells.

- The state of mind and the body are intimately related at the time of stress. As Glucagon secretion is enhanced by a variety of stressors, Yogāsana (yogic practices) and Prānāyam (breathing practices) effectively reduce the stress, and level of Glucagon and possibly improve insulin action at the peripheral muscles.

Therefore, regular practice of Yoga and a controlled lifestyle reduces blood sugar load in people with diabetes. Although there are various practicing methods and implementation of Yoga therapy, however, the data show that yoga has a significant short-term effect on a variety of health-related outcomes.

\section{CONCLUSION}

Diabetes is a severe and lifelong ailment. It cannot completely cure, but effective control on blood sugar level and prevent or postpone the diabetes-related complications. Yoga-based treatment has recently emerged as a potential technique for the prevention of lifestyle diseases, including diabetes. It targets increased cholesterol and blood glucose levels in diabetic patients by incorporating an integrated strategy of Yoga. Yoga practices have given multiple health benefits and management tools for metabolic disorders. As a result, we may infer that Yogāsana (yogic practices) and Prānāyam (breathing practices) have shown some promise in managing diverse clinical problems. It can be used in conjunction with other medical systems as an adjuvant for health maintenance, as well as the prevention and treatment of illnesses.

\section{ACKNOWLEDGEMENT:}

The author is a PhD. Scholar and a senior research fellow are receiving funds from CCRAS New Delhi (Ministry of AYUSH, Govt. of India). However, the funding source played no part in the preparation or composition of the present review work.

\section{REFERENCES}

1. Members [Internet]. www.idf.org [cited 2020 Dec 30]. Available from: https://www.idf.org/ournetwork/regions-members/south-eastasia/members/94-india.html

2. Lasater J. Restorative Yoga. 1nternational Journal of Yoga Therapy. 1997 Jan 1;7(1): 22-6.

3. Pandey Ajai Kumar, Byadagi P. S. A textbook of Kayachikitsa. Vol. I. New Delhi, India. 470-800, Chaukhambha publications; 2013.

4. Maehle G. Ashtanga Yoga: Practice and Philosophy. Analoo City.Western Australia: kaivalya publication; 2006.

5. Collins C. Yoga: Intuition Preventive Medicine Treatment. journal of Obstetric, Gynecologic \& Neonatal Nursing. 1998 Sep; 27(5):563—8.

6. Maehle Gregor; Ashtanga Yoga: Practice and Philosophy. I' edition, New world library California, USA, 2007.

7. Vaishali K, Kumar KV, Adhikari P, Unnikrishnan B. Effects of Yoga-Based Programon Glycosylated Heamoglobin Level Serum Lipid Profile in Community-Dwelling Elderly Subjects with Chronic Type 2 Diabetes Mellitus-A Randomized Controlled Trial. Physical \& Occupational Therapy ln Geriatrics. 2012 Feb 13; 30(1):22-30.

8. Vizcaino M, Stover E. The effect of Yoga practice on glycemic control and other health parameters in Type 2 diabetes mellitus patients: A systematic review and meta-analysis. Complementary Therapies in Medicine. 2016 Oct; 28:57-66.

9. Chimkode SM. Effect of Yoga on Blood Glucose Levels in Patients with Type 2 Diabetes Mellitus. JOURNAL OF CLINICAL AND DIAGNOSTIC RESEARCH. 2015 ; 
10. Vaishali K, Kumar KV, Adhikari P, Unnikrishnan B. Effects of Yoga-BasedProgramon Glycosylated Hemoglobin Level Serum Lipid Profile in CommunityDwelling Elderly Subjects with Chronic Type 2 Diabetes Mellitus-A Randomized Controlled Trial. Physical \& Occupational Therapy in Geriatrics. 2012 Feb 13; 30(1):22-30.

11. Singh S, Kyizom T, Singh KP, Tandon OP, Madhu SV. Influence of Prānāyams and Yoga-asanas on serum insulin, blood glucose and lipid profile in type 2 diabetes. Indian Journal of Clinical Biochemistry. 2008 Oct; 23(4):365-8.

12. Upadhyay AK, Balkrishna A, Upadhyay RT. Effect of Pranayam [Voluntary Regulated Yoga Breathing] and Yogasana [Yoga Postures] in Diabetes Mellitus (DM): A Scientific Review. Journal of Complementary and Integrative Medicine. 2008 Jan 15; 5(1).

13. Malhotra V, Singh S, Singh KP, Sharma SB, Madhu SV, Gupta P, et al. Effects of Yoga asanas and Prānāyamin non-insulin-dependent diabetes mellitus. Indian Journal of Traditional Knowledge. 2004 Apr; 3(2): I 62-7.

14. Taskinen M-R. Diabetic dyslipidemia. Atherosclerosis Supplements. 2002 May; 3(1):47-51.

15. Mooradian AD. Dyslipidemia in type 2 diabetes mellitus. Nature clinical practice Endocrinology \& metabolism [Internet].2009 [cited 2019 Dec 11]; 5(3): 150-9. Available from: https://www.ncbi.nlm.nih.gov/pubmed/19229235

16. Bisht S, Sisodia S. Diabetes, dyslipidemia, antioxidant and status of oxidative stress. International Journal of Research in Ayurveda and Pharmacy. 2010; 1(1):33-42.

17. Gadham J, Sajja S, Rooha V. Effect of Yoga on obesity, hypertension and lipid profile. International Journal of Research in Medical Sciences. 2015; 3(5): $106 \mathrm{I}$.

18. Mondal S, Kundu B, Saha S. Blood Sugar and Lipid Profile Adaptations to Yoga Therapy. J Yoga Phys Ther [Internet].2014 [cited 2020 Dec 30]; 4:175. Available from: https://www.omicsonline.org/open-access/bloodsugar-and-lipid-profile-adaptations-to-Yoga- therapy2157-7595.1000175.php'?aid=32550

19. Shantakumari N, Sequeira S, El deeb R. Effects of a Yoga intervention on lipid profiles of diabetes patients with dyslipidernia. 1ndian Heart Journal [Internet]. 2013 Marl [cited 2020 Jun 13]; 65(2):127-131.
Available

from:

https://www.ncbi.nlm.nih.gov/pmc/articles/PMC3861 018/

20. Bhardwaj PR, Bhardwaj AK. Therapeutic Applications of Yoga for Weight Reduction in Obese Population: An Evidence-Based Overview. Online Journal of Multidisciplinary Research. 2015 Apr; 1(1): 1-5.

21. Prasad KVV. EFFECT OF YOGA ON WEIGHT AND FAT FOLD THICKNESS IN OBESE WOMEN. www.academia.edu [Internet]. 2003 May 1 [cited 2020 Dec 30] ;Available from: https://www.academia.edu/7019373/effect_of_Yoga_ on_weight_and_fat_fold_thickness_in_obese_women

22. Hegde SV, Adhikari P, Kotian S, Pinto VJ, D'Souza S, D'Souza V. Responseto Comment on Hegde et al. Effect of 3-Month Yoga on Oxidative Stress in Type 2DiabetesWithor Without Complications: A Controlled Clinical Trial. Diabetes Care 2011; 34:22082210. Diabetes Care. 2012 May 22; 35(6):e43-e43.

23. blood pressure and you/your body/diabetes. http://www.bloodpressureuk.org. Wolfson Institute of Preventive Medicine, Charterhouse Square, London, EC I M 6BQ.

24. DalsingerMicheal. Diabetes and High Blood Pressure. www.webmed.com. 2019.

25. Dhungana RR, Khanal MK, Joshi S, Kalauni OP, Shakya A, Bhrutel V, et al. Impact of a structured Yoga program on blood pressure reduction among hypertensive patients:study protocol for a pragmatic randomized multicenter trial in primary health care settings in Nepal. BMC Complementary and Alternative Medicine. 2018 Jul 5; 18(1).

26. Yang H, Jin X, Kei Lam CW, Yan S-K. Oxidative stress and diabetes mellitus. Clinical Chemistry and Laboratory Medicine. 20 I IJan 1;49(11).

27. Hegde SV, Adhikari P, Kotian S, Pinto VI, D’Souza S, D'Soiiza V. Effect of 3-Month Yoga on Oxidative Stress in Type 2 Diabetes With or Without Complications: A controlled clinicaltrial. Diabetes Care [Internet]. 2011 Aug 1 [cited 2019 Dec 10]; 34/10/:220810.

Availablefrom: https://care.diabetesjournals.org/content/34/10/2208.a bstract

28. Falck S. Diabetes and mood swings: Effects on relationships and lifestyle tips [Internet]. Medical News

Today. 2017. Available from: https://www.medicalnewstoday.com/articles/317458. php 
29. Kalra S, Khandelwal D, Dutta D, Chittawar S. Sleep disorders in type 2 diabetes. Indian Journal of Endocrinology and Metabolism [Internet]. 2017; 21(5):758. Available from: https://www.ncbi.nlm.nih.gov/pmc/articles/PMC5628 550/

30. Bankar M, Chaudhari S, Chaudhari K. Impact of long term Yoga practise on sleep quality and quality of life in the elderly. Journal of Ayurveda and Integrative Medicine. 2013; 4(1):28.

31. Diabetes Type 2 Depression, feeling down and mood swings [Internet]. healthtalk.org. [cited 2020 Dec 30]. Available from: http://www.healthtalk.org/peoplesexperiences/long-term- conditions/diabetes-type2/depression-feeling-down-and-mood-swings

32. Chen K-M, Chen M-H, Chao H-C, Hung H-M, Lin $\mathrm{H}-\mathrm{S}$, Li C-H. Sleep quality, depression state, and health status of older adults after silver yoga exercises: Cluster randomized trial. International Journal of Nursing Studies. 2009 Feb; 46(2): 154-63.

33. Cohen L, W arneke C, Fouladi RT, Rodriguez MA, Chaoul-Reich A. Psychological adjustment and sleep quality in a randomized trial of the effects of a Tibetan Yoga intervention in patients with lymphoma. Cancer. 2004; 100(10):2253-60.

34. Chen K-M, C hen M-H, Lin M-H, Fan I-T, Lin H-S, Li C-H. Effects of Yoga on Sleep Quality and Depression in Elders in Assisted Living Facilities. Journal of Nursing Research. 2010 Mar; 18(1):53-61.

35. M.D TM. The Scientific Basis of Yoga Therapy [Internet]. Yoga Journal. [cited 2020 May 25]. Available from: https://www.Yogajournal.com/teach/thescientific-basis-of-Yoga- therapy

36. K. Vaishali, K. V ijaya Kumar, Adhikari P, B. UnniKrishnan. Effects of Yoga-Based Program on Glycosylated Hemoglobin Level Serum Lipid Profile in Community-Dwelling Elderly Subjects with Chronic Type 2 Diabetes Mellitus-A Randomized Controlled Trial. Physical \& Occupational Therapy in Geriatrics [Internet]. 2012 [cited 2021 Jan 1]; 30(1):22-30. Available from: http://eprints.manipal.edu/id/eprint/3264

37. Phatak MS, Chawla TG, Phatak PS. Effect of raja Yoga meditation on glycaemic status in type 2 diabetes mellitus. International Journal of Research in Medical Sciences.2017 Sep 28; 5(10):4385.

38. Langille J. Can Yoga Help You Reduce Your Medications [Internet]. MedShadow. 2014 [cited 2021 Jan
1]. Available from: https://medshadow.org/can-Yogahelp-reduce-medications/

39. Dr. Ravi Kant Prajapati, Ajai Kr Pandey, Mangalagowri Rao. Role of Yava (Barley) Based And Yogic Practices In Management Of Madhumeha (Diabetes Mellitus) [Internet]. ResearchGate. unknown; 2017. [Cited 2021 Jan 1]. Available from: https://www.researchgate.net/publication/322267725 _ROLE_OF_YAVA__ BARLEY_BASED_DIET_AND_YOGIC_PRACTICES_I N_MANAGEMENT_OF_MADHUMEHA_DIABET ES_MELLITUS

40. Pandey Ajai Kumar, Singh Ram Harsh: A Study of the Immune status in patients of diabetes mellitus and their Management with certain Naimittika Rasayana drugs. JRAS. 2003; XXIV. (3-4):48-61.

41. Sahay BK. Proceedings of Novo Nordisk Diabetes Update. Bombay: Ed. Anil Kapur, Publ. Health Care Communications. Yoga and Diabetes. 1994; 159-67.

\section{Source of Support: Nil Conflict of Interest: None Declared}

How to cite this URL: Rashmi Kathait \& Ajai Kumar Pandey: Preventive And Therapeutic Effect Of Yogāsana And Prānāyam In The Patients Of Diabetes Mellitus: An Overview. International Ayurvedic Medical Journal \{online\} 2021 \{cited October 2021\} Available from: http://www.iamj.in/posts/images/upload/2415_2422.pdf 